\title{
Sobre a possibilidade de violar um dever jurídico com vistas à observância de um preceito moral segundo Kant
}

\section{On the possibility of violating a legal duty with a view to the observance of a moral precept according to Kant.}

\author{
CLAITON DERLI SEIBERT POERSCH ${ }^{1}$
}

\begin{abstract}
Resumo: Propõe-se com este estudo bibliográfico analisar, a partir das exposições de Immanuel Kant e seus comentadores, a relação entre o Imperativo Categórico e a moralidade que dele emana frente aos pressupostos da legislação jurídica e suas peculiaridades, analisando-os de tal forma a compreender o embate que há entre ambos e construindo um panorama a partir do qual se vislumbre uma solução ao questionamento: "pode o indivíduo violar um preceito jurídico com vistas à observância de um dever moral?". A partir das análises realizadas, visualiza-se que a proposta moral de Kant permite uma construção sistêmica do tema, pois, a partir da elucidação do Imperativo Categórico e suas nuances quanto aos aspectos morais e; concomitantemente, partindo do prisma da legalidade e suas implicações, permitiu-se verificar que, mesmo frente à força coercitiva da lei, característica esta essencial ao preceito jurídico; é o preceito moral que se impõe e faz valer seu atributo primordial, qual seja, o da universalidade capaz de conduzir a humanidade a um progresso ao Reino dos Fins.
\end{abstract}

Palavra-chave: Direito. Dever jurídico. Dever moral.

Abstract: It is proposed with this bibliographical study analyze, from exhibitions of Emmanuel Kant and his commentators, the relation between the Categorical Imperative and the morality of it release front of the presuppositions of legal legislation and their peculiarities, analyzing them in such a way as to understand the clash between both and building a view from which to glimpse a solution to the question: "Can an individual violating a legal precept with views to compliance with a moral duty ?" . From the analyses realized, you will see that the propose of the moral Kant allows a systemic build of the topic, because, from the elucidation of the Imperative Categorical, and their nuances as to the moral aspects, and; at the same time, fromthe prism of legality and their implications, allowed to verify that, even the front of the coercive force of the law, this characteristic is essential to the precept legal; it is the universality able to lead the humanity to a progress and Kingdom of Ends.

Key Word: Right. Legal duty. Moral duty.

\section{Introdução}

Immanuel Kant revelou-se um grande pensador do período moderno, seja no âmbito da Filosofia, quanto do Direito, notadamente após a publicação de sua obra intitulada A Fundamentação da Metafísica dos Costumes (1785).

${ }^{1}$ Licenciado em Filosofia (PUCPR). Bacharel em Direito (PUCPR). Advogado. Mestrando em Filosofia (UNIOESTE). E-mail: claitonpoersch@hotmail.com 
Dentre tantos aspectos que sobressaem de sua teoria, evidencia-se a relação entre o dever moral e o jurídico, razão pela qual buscar-se-á, com o presente, analisar ao indivíduo á facultada esta possibilidade de transgredir a lei com vistas à observância de um preceito moral.

Para tanto, apresentar-se-á as nuances alusivas ao imperativo categórico aspecto fulcral da proposta moral de Kant; elucidando a peculiaridade dessa moral, qual seja, de ser eivada de universalidade, arredada de quaisquer elementos empíricos.

Num segundo momento, perscrutar-se-ão as sutilezas que envolvem a relação entre os deveres morais e jurídicos, eis que, a partir destas, perceber-se-á que, enquanto a legislação jurídica apresenta como pilar a lei oriunda do Estado e a coercibilidade que dela emana frente ao indivíduo, o Imperativo Categórico kantiano e, consequentemente, a proposta moral dele emanada, tem como espeque a execução de um ato, apenas, por dever e não motivado por quaisquer outros elementos.

Enquanto a moralidade é erigida pelo princípio da universalidade e fundamentada no dever, o preceito jurídico é marcado pelo caráter da coercibilidade, não importando a motivação interna do sujeito.

Por fim, buscar-se-á analisar a possibilidade de o sujeito de transgredir uma norma jurídica com vistas à observância de um preceito moral. Para tanto, elucidarse-ão os contornos sobre os quais se fixam a lei moral e jurídica e como ambas se relacionam em âmbito estatal, sobretudo no que tange às discrepâncias quanto ao caráter de cada uma delas.

A partir dessa análise, vislumbra-se um aparente paradoxo na teoria kantiana quando da colisão entre uma lei jurídica e um preceito moral, cuja solução parece apontar para a possibilidade de desobediência civil, garantindo assim uma forma de garantir a observância do dever moral e a soberania do poder estatal.

\section{O imperativo categórico como o cerne da ação moral em kant}

A proposta moral apregoada por Immanuel Kant se consolida a partir do Imperativo Categórico e busca fundamentar-se de forma a priori, despojada de quaisquer elementos oriundos da empiria, pois estes maculam a essência da moralidade e desnaturam sua peculiaridade, qual seja, ser universal.

O imperativo categórico, de acordo com Perez (2009, p. 149), seria o enunciado o qual determina as máximas subjetivas da ação do indivíduo, uma fórmula sem matéria; já permitindo verificar alguns direcionamentos centrais sobre os quais se delineiam o estudo do agir pelo dever, tais como o fato de agir sem esperar recompensa alguma, realizando uma ação com um fim em si, apenas. Nesse sentido, apregoa Kant: 
nesta catequese, que deve ser levada a cabo através de todos os artigos da virtude e do vício, o maior cuidado precisa ser tomado no sentido de basear o comando do dever não nas vantagens ou desvantagens resultante de observá-lo, se é o caso de submeter à obrigação um ou mesmo os outros, mas por completo puramente no princípio moral. (KANT, 2003, p. 325)

A ação que emana de tal imperativo deve servir como fundamento universal de todas as ações empreendidas pela subjetividade. O próprio Kant (1974, p. 209) ainda enfatiza que "[...] o valor moral da ação não reside, portanto, no efeito que dela se espera; também não reside em qualquer princípio da ação que precise de pedir o seu móbil a este efeito esperado". Desse modo, ao verificar se uma ação está imbuída de moralidade ou não, deve-se atentar que o efeito desse agir não pode ser levado em consideração ao almejar realizar uma atitude, pois tal empreendimento poderia ensejar uma ação, apenas, em conformidade ao dever, ou como apregoa Sánchez Vázquez (2013, p. 193), "uma ação pode cumprir-se conforme o dever, mas não por dever, e sim por inclinação ou interesse; neste caso, não será moralmente boa"; isto é, quando interesses estiverem regendo as ações, estas deixam à mercê qualquer possibilidade de serem qualificadas como uma ação moral. Tal situação também fora apregoada por Pinheiro (2007, p. 17), em cujo pensamento expressa que “[...] mesmo uma boa ação, cumprida por interesse, por prazer, ou por qualquer outra intenção, que não a pura ação por dever, não possui qualquer valor moral”.

No Imperativo Categórico não há espaço para subjetividade, não se admitindo uma ação empreendida com vistas a outro fim, mas apenas o agir por dever (APOLINÁRIO, 2012, p. 45), e ainda, nas palavras de Kant, este imperativo "declara a ação como objetivamente necessária por si, independentemente de qualquer intenção" (2008, p. 219), sendo perceptível que tal exposição permite ver o fundamento da ação moral no Imperativo Categórico, ou seja, que é nele que se encontra o fomento a partir do qual pode o agente praticar uma ação sugestionado, apenas, da prática do dever pelo dever, haja vista que:

o que conta para a ética não são os sentimentos ou o sucesso da ação, mas as máximas da vontade humana e sua subordinação ao imperativo categórico, a única que pode orientar a ação humana. (OLIVEIRA, 2005, p. 12)

Os elementos supra já denotam as peculiaridades do imperativo categórico e o filósofo expressa-o na seguinte fórmula: "age de tal modo que a máxima de tua vontade possa sempre valer ao mesmo tempo como princípio de uma legislação universal" (KANT, 2008, p. 51); e esta maneira de expor é explicada por Tugendhat como:

entende-se por imperativo categórico uma regra da razão sem ponto de referência; seria então racional fazer algo, não com referência a 
um determinado objetivo e também não em vista do bem-estar de quem age (ou faz) ou de um outro ser, mas em si mesmo. (TUGENDHAT, 2003, p. 43)

Verifica-se que a lei, para ser assumida como princípio universal, carrega em sua essência o próprio dever, não necessitando de ingerência alheia à sua execução, sobretudo se levado em consideração que a lei moral não pode estar pautada em condições empíricas, pois "os imperativos categóricos são os que representam uma ação como objetivamente necessária por si mesma” (SOUZA, 2009, p. 68). Diante disso, é passível de compreensão que no Imperativo Categórico há a essência e a própria moralidade da ação, tendo sido explicitado por Kant, conforme segue:

o princípio supremo [do agir...] é, portanto: age com base em uma máxima que pode também ter validade como uma lei universal. Qualquer máxima que não seja assim qualificada é contraria à moral. (KANT, 2003, p. 68)

Chega-se, a partir desses elementos, à ideia de que a ética kantiana é deontológica, ou seja, primeiro estabelecendo o parâmetro do que é obrigatório/correto; para, posteriormente, preocupar-se com o bem. Esta conjuntura é trazida, também, por Beckenkamp (2009, p. 64) sendo enfático ao elucidar que "[...] só imperativos propriamente morais comandam categoricamente, quer dizer, sem requerer ou mesmo admitir qualquer condição". Se fosse feito o caminho inverso, realizar-se-ia o bem com vistas ao que é correto, isto é, o agir estaria imbuído de uma característica que não o dever, sendo que o justo deve preceder o bem, não excluindo, contudo, este último; além de que, conforme expõe Pavão (2007, p. 103), o conceito de "Dever" não pode ser abstraído de conceitos empíricos, pois é impossível encontrar neles a perfeita abstração do que seja um agir moral.

Sendo assim, parte-se da premissa que o imperativo categórico é carregado de uma característica essencial: a universalidade. Explica Candiotto (2011, p. 98) que “[...] a única máxima que poderá ser transformada em lei moral é aquela que pode ser universalizada para todos os demais seres racionais", e não apenas para o homem. E quanto a isso, o próprio Kant (2008, p. 6o) aponta que "a lei moral [...] só é pensada como objetiva e necessária, porque deve valer para qualquer um que tem razão e vontade". Acrescenta ainda o filósofo alemão que "[...] aquilo que é dever apresenta-se por si mesmo a qualquer um [...]”. (KANT, 2008, p. 6o)

Tais aspectos permitem verificar que o preceito moral é estendido a todo ente racional e, sendo assim, apresenta-se como necessário a todos, corroborando a ideia central de "universalidade". Assim, para ser universalizável, o imperativo deve valer a qualquer indivíduo indistintamente e, para tanto, Kant (2008, p. 147) propôs um silogismo capaz de orientar o agir, segundo o qual há a Premissa Maior, esta caracterizada pelo universal, conformando-se com o Princípio Moral; uma Premissa Menor, na qual se enquadram possíveis ações do indivíduo; e por fim, a Conclusão, 
que seria a determinação subjetiva da vontade. Neste panorama, pode-se visualizar que a síntese é a busca de uma ação essencialmente pautada pelo imperativo categórico, pois "quando nossas máximas são determinadas pelo imperativo categórico e não pelas nossas inclinações sensíveis, então agimos moralmente bem" (PEREZ, 2009, p. 150).

Além do mais, não se pode olvidar que o imperativo categórico é denominado de "Lei", haja vista sua característica essencial: a universalidade; sendo tal condição esclarecida por Souza ao ressaltar que:

[...] fica estabelecida a característica principal de uma lei: a universalidade, ao passo que a máxima se caracterizaria pela contingência. E se uma lei tem por essência a universalidade, então, tem de poder valer para todos os casos sem admitir exceções. (SOUZA, 2009, p. 64)

É precisamente essa universalidade inerente ao Imperativo Categórico que o torna singular e imprescindível à construção de fórmulas morais. Coerente com sua proposta, Kant não admite exceções na formulação dos princípios morais, pois, para ele:

[...] os princípios morais não podem admitir essas condições adicionais, mas tem que manter a sua formulação categórica: 'tu deves fazer X' ou ' não deves fazer Y' [... pois do contrário] os princípios perderiam seu próprio sentido como princípios morais, se incluíssem condições adicionais. Nesse caso deixariam de ser princípios categóricos, porque esses são absolutamente incondicionados e passariam a ser juízos hipotéticos, pois estariam sujeitos a condições.(DURÃO, 1998, p. 117)

Vislumbra-se, à luz dos elementos ora analisados, que o filósofo almejou algo que atendesse de modo universal, sendo este o requisito fundamental por constituir-se em conditio sine qua non para assimilar a mudança engendrada na consideração moral; mas além disso almejou alcançar um patamar mais elevado:

[...] sob a égide dos fins universalmente válidos, [Kant] declara a possibilidade de uma condução da humanidade para fins comuns: tal conceito Kant denominou Reino dos Fins. [...] A efetivação do reino dos fins decorreria das máximas que instituíssem suas regras em sintonia com o imperativo categórico, sendo seguidas de modo universal por todos os seres racionais. (APOLINÁRIO, 2012, p. 48)

A respeito da implementação de um Reino dos Fins, no qual as ações dos indivíduos seriam pautadas em máximas decorrentes do imperativo categórico, criando uma "Constituição Universal”, Durão tece uma crítica a essa conjuntura moral propugnada por Kant, asseverando que ela é, essencialmente, rigorista, haja vista insistir em uma formulação categórica, inaplicável ao contexto, visando 
somente o Reino dos Fins: “[...] proliferam as críticas de que a filosofia prática kantiana só tem validade pensada dentro do campo de teologia moral e perde o seu sentido e significado fora dela" (DURÃO, 1998, p. 117).

Depreende-se, alicerçado nos argumentos retro, que a implementação de um Reino dos Fins é o sonho almejado por Kant, mas que esbarra em elementos singulares, porém substanciais. Somente a partir do momento em que os entes racionais pautarem suas ações em uma legislação universal, fato este que possibilita aos sujeitos agirem consoante os preceitos da moralidade, é que haverá uma contribuição para o surgimento de uma consciência moral a qual "[...] começa a emergir propriamente [...] quando o homem cumpre normas que regulamentam os seus atos [... porque] compreende o dever de cumpri-las" (SÁNCHEZ VÁZQUEZ, 2013, p. 188).

Diante dessas circunstâncias, tem-se que, para Kant, é no imperativo categórico que se encontra o suprassumo da moral, muito embora haja críticas quanto à sua efetivação na prática; e é a partir dele que se extrai os elementos necessários à concretização da moralidade.

\section{$3 \mathrm{O}$ dever jurídico e o dever moral}

Como já mencionado, o agir moral deve ser guiado não por inclinações ou outros móbeis externos, mas por puro dever, cuja essência se encontra em si, não necessitando do aparato legal para lhe conceder eficácia.

Da teoria de Kant, extrai-se o elemento dever, a partir do qual são delineadas as facetas com as quais se compõe o Imperativo Categórico. Segundo o filósofo, "[...] o conceito de dever exige na ação, objetivamente, concordância com a lei, mas na sua máxima, subjetivamente, respeito pela lei, como o único modo de determinação da vontade pela lei”(KANT, 2008, p. 131).

Desse pensamento é possível analisar e extrair duas atitudes: a Ação Conforme ao Dever e o Agir por Dever - àquela remete-se o conceito de legalidade, na qual se verifica que o fundamento da ação pode estar nas inclinações. Nesse sentido, explica Mattos:

em todas as ações jurídicas, a legalidade é conformidade ao dever, mas não moralidade, pois elas não ocorrem por dever. Na legalidade só importa se eu ajo de acordo com o dever, sendo indiferente se o faço por respeito ou inclinação e medo. (MATTOS, 2010, p. 111)

Já nas ações por dever, vincula-se a moralidade, quando se age, simplesmente, por causa da lei. E nesta seara é salutar esclarecer o que fora elencado por Beckenkamp ao distinguir o jurídico do ético, preconizando que: 
[...] a ética só admite como móbil para o cumprimento da lei o próprio dever ou, em termos da sensibilidade, o respeito pela lei, enquanto o direito não só admite, mas mesmo requer um móbil determinante do arbítrio distinto do próprio dever, ou seja, um móbil não ético [...]. (BECKENKAMP, 2009, p. 69)

Portanto, não resta dúvida que, para Kant, não há qualquer possibilidade de vinculação da moral a fatores empíricos, pois "mesmo uma inclinação ao que é conforme ao dever (por exemplo, à caridade) pode, em verdade, facilitar muito a eficácia das máximas morais mas não pode produzir nenhuma delas" (KATN, 2008, p. 191). Isso é manifesto quando, ao realizar-se uma averiguação profunda na teoria moral kantiana, percebe-se que é preciso estar voltado à representação da lei como fundamento determinante, e não outro; sendo eminentemente necessário, consoante o filósofo "[...] que as ações não ocorram apenas em concordância com o dever (em consequência de sentimentos agradáveis) e, sim, por dever, o que tem de ser o verdadeiro fim de toda a cultura moral" (KANT, 2008, p. 191).

O rol de elementos trazidos à discussão por Kant é amplo e autores hodiernos, tais como Apolinário, asseguram que as ações conforme ao dever visam um fim (telos), enquanto as ações por dever (nas quais há moralidade) são pautadas em uma máxima, abstendo-se de quaisquer interferências externas, enfatizando que "o dever constitui a intenção obrigatória do sujeito que se submete ao imperativo categórico, legitimando o exercício de uma moralidade pura objetiva, porque completamente racional”. ( 2012, p. 44)

Ora, apesar de ser um ente instituído de razão, mas também sujeito a interferências do âmbito externo, engendrando, portanto, um ser que está oscilando entre o caráter racional, que almeja a moralidade; e de outro lado, o viés da inclinação; vê-se um sujeito imerso em uma realidade cujas ramificações e estruturação o colocam sempre frente a um conflito; exige-se dele uma ação e ao assumir um posicionamento, deve ele portar-se de acordo com os ditames da moralidade ou da legalidade? Ou ainda, pode ele congregar tais componentes e, mesmo assim, pautar sua ação sob a égide da moral? Tais questionamentos permitem entrever um vasto horizonte pelo qual se delineiam os caracteres da moral kantiana, pois em cada um desses elementos assenta-se um dogma do autor, de onde sobressai não apenas indícios, mas requisitos para a formulação e compreensão de seu imperativo do agir.

Ao fazer a distinção do agir conforme a lei do agir por dever, Kant esclarece:

o essencial de todo valor moral das ações depende de que a lei moral determine imediatamente a vontade. Com efeito, se a determinação da vontade acontecer conforme à lei moral, mas somente através de um sentimento, seja ele de que espécie for e que tenha de ser pressuposto para que a lei moral se torne um fundamento determinante suficiente da vontade, por conseguinte 
Sobre a possibilidade de violar um dever jurídico com vistas à observância de um preceito moral segundo Kant

não por causa da lei, nesse caso a ação em verdade conterá legalidade mas não moralidade. (KANT, 2008, p. 114)

Arremata-se do exposto que se o agir estiver apenas em conformidade com a lei, imbuído de um sentimento qualquer e não por causa da lei, haverá legalidade, contudo, não moralidade; pois "pode-se dizer de cada ação conforme à lei, que, contudo, não ocorreu por causa da lei, que ela seja moralmente boa apenas segundo a letra, mas não segundo o espírito (segundo a disposição).” (KANT, 2008, p. 116)

Verifica-se, pois, aqui que a intenção, o motivo da ação é preponderante para auferir se a ação é moralmente boa ou não, de tal forma que:

[...] se uma criatura racional pudesse alguma vez chegar a praticar as leis morais inteiramente de bom grado, isso equivaleria a que não se encontrasse nela sequer a possiblidade de um apetite que o estimulasse a desviar-se delas; pois o domínio de um tal apetite sempre custa sacrifício ao sujeito, portanto requer autocoerção, isto é, necessitação íntima para o que não se faz inteiramente de bom grado. (KANT, 2008, p. 135)

Extrai-se deste pensamento que não pode o homem abster-se de suas volições empíricas, devendo, contudo, chegar o mais próximo possível da denominada "perfeição", pois a natureza humana possui uma destinação moral que é alcançar plena conformidade com a lei moral e, embora, jamais alcancem aquela perfeição (adequação plena de seu agir ao que é moralmente correto), é-lhe oportunizado progredir do pior para o moralmente melhor.

E esse progresso é atingido à medida que há uma disposição para a moralidade, agindo por dever e buscando, sempre, o caráter essencial, qual seja, o “dever” como princípio da ação, pois:

[...] somente às ações realizadas por dever pode ser atribuído valor incondicional e, por conseguinte, podem ser consideradas válidas moralmente, ao passo que as ações resultantes de outros princípios quando muito podem conter legalidade, mas não moralidade, por estarem ligadas à satisfação particular das inclinações de determinado sujeito que visa neste caso sua própria felicidade. (SOUZA, 2009, p. 83)

Kant certamente oferece um item central para aprimorar tal exposição, pois quando versa a respeito dos fundamentos determinantes da vontade, assevera que:

[...] a imediata representação da lei e o objetivamente necessário cumprimento da mesma como dever -, que única e propriamente tornam morais as máximas e dão-lhe um valor moral, têm que ser representados como os autênticos motivos das ações; porque, do contrário, sem dúvida se produziria legalidade das ações, mas não moralidade das disposições. (KANT, 2008, p. 239) 
É incontestável, em vista disso, a discrepância que há entre o aspecto legal e a moral na análise proposta por Kant, mormente pelo fato de que tal investigação apresenta um caminho único a ser trilhado, qual seja, o de agir sob a égide da lei moral. Para tanto, a ação deve ser realizada por dever e não por outro fim, por mais nobre que seja, mesmo que tal fim seja o de fazer o "bem", conforme preconiza Candiotto (2011, p. 10o), destacando que para o Kant mais importa seguir a lei, de forma racional e, somente depois, se for o caso, fazer o bem.

Tal característica é notória na proposta kantiana, pois o filósofo vai muito mais além, construindo uma moral que não necessita ser palpável, que prescinde do "fazer o bem" e se permite estar vinculado à essencialidade da ação, não se atendo a elementos fugazes, os quais, em muitas circunstâncias, desviam o foco daquilo que efetivamente é fulcral - a saber, a ação por dever.

E o antagonismo de interesses presente no ser humano permite ancorar em um outro porto, desconhecido e repleto de interrogações: se o sujeito vê sempre seu íntimo em um guerrear constante entre as inclinações e a razão prática pura, devendo, contudo, optar para qual lado pender; sua escolha está balizada pelo interesse moral ou pelo interesse sensível? Ou por nenhum dos dois? Como saber qual o mandante da ação?

Tais indagações trazem à reflexão outro conceito abordado por Kant: a liberdade. À primeira vista, parece uma resposta simples e que não ensejariam grandes divergências. Entretanto, faz-se mister compreender a dinâmica de tal conceito à luz da proposta kantiana; e quem oferece um posicionamento consistente é Souza ao destacar que:

somente é possível julgar as ações humanas sob uma perspectiva ética, se pudermos pressupor que foram realizadas de acordo com uma vontade livre. É impossível imputar responsabilidade moral a uma ação necessariamente causada por uma determinação distinta da causalidade por liberdade. (SOUZA, 2009, p. 119)

Tal "vontade livre" é essencial para a compreensão da constituição da moral, tendo em conta que o próprio Kant assevera que:

o essencial de toda determinação da vontade pela lei moral é que ela, enquanto vontade livre - por conseguinte, não apenas independente do concurso de impulsos sensíveis mas, mesmo com a rejeição de todos eles e pela ruptura com todas as inclinações, na medida em que pudessem contrariar aquela lei -, é determinada simplesmente pela lei. (KANT, 2008, p. 117)

Do exposto, um questionamento ainda pode surgir: como ser "vontade livre" se é determinada pela lei? Primeiramente, é plausível enaltecer o que fora expresso por Pavão a respeito da denominada "vontade livre", preconizando que ela: 
Sobre a possibilidade de violar um dever jurídico com vistas à observância de um preceito moral segundo Kant

[...] é uma vontade autônoma. Isso quer dizer que ela, sendo lei para si mesma, não adota senão uma máxima que pode 'ter-se a si mesma por objeto como lei universal. Isto, porém, é precisamente a fórmula do imperativo categórico e o princípio da moralidade; assim pois, vontade livre e vontade submetida a leis morais são uma e mesma coisa"'(PAVÃO, 2002, p. 123).

Desse modo, e conforme apresentado anteriormente, a única forma de se chegar à moral é agindo por dever. Nesse sentido, explica Souza:

uma ação, no âmbito da ética kantiana, só possui retidão moral se ela for realizada por dever, ou seja, se for realizada de acordo com a lei fundamental da razão prática pura. Somente assim tal ação poderá ser considerada livre, isto é, se a realização da mesma for causada por uma vontade incondicionada, diferentemente do que ocorreria se a vontade tivesse sido determinada por princípios empíricos. Ser livre, portanto, é agir por dever (SOUZA, 2009, p. 127).

É esclarecedor tal posicionamento, pois ao agir pautado pela ideia de liberdade, admite-se que ele está agindo consoante as leis do mundo inteligível, por conseguinte, de acordo com a lei moral. E é nessa característica, pela ideia e noção de liberdade, que é retirado do indivíduo todo interesse empírico para então demonstrar o interesse racional pela ação. À vista desse conglomerado, tem-se, portanto, de um lado a legislação ética e de outro a legislação jurídica, sentenciando cada uma sua verdade a respeito da "liberdade": aquela fundamenta a lei da liberdade interna, enquanto a legislação jurídica versa acerca da liberdade externa (OLIVEIRA, 2005, p. 11), assumindo cada qual sua finalidade.

A respeito desse elemento, é salutar evidenciar o que preconiza Salgado:

[...] a finalidade do Direito é, tão somente, a de resguardar a máxima de que a liberdade de um termina onde começa a liberdade do outro. Para isso, o Direito apresenta como característica fundamental a coercibilidade. (SALGADO, 2007, p. 349)

E aqui começa a se delinear de modo mais cristalino o que é possível visualizar nos preceitos atinentes ao Direito, a partir dos quais constrói-se esse mosaico denominado de lei jurídica.

É manifesto e incisivo o modo como afloram os preceitos alusivos ao Direito a partir da coercibilidade a ele inerente. Tanto isso é perceptível, que Machado oportuniza uma exposição clara a respeito:

[...] o que leva ao agir moral na Ética é o respeito, enquanto que no Direito essa função é desempenhada pela possibilidade de uma coação externa. Assim, para Kant, o Direito será necessariamente Moral, mas, ao mesmo tempo, irredutivelmente distinto do Ético. (MACHADO, 2011, p. 12) 
O que se verifica desses preceitos é que se o Direito vela, apenas, de aspectos externos ao sujeito, não precisa atentar àquilo que serve de mote para o agir, quer dizer, se o indivíduo agiu conforme ou por dever, constituindo-se assim em uma diferenciação substancial: "o direito, porque cuida apenas da relação exterior entre os arbítrios, pode deixar de lado qualquer consideração quanto às intenções dos agentes." (PERES, 1998, p. 45)

Dessarte, tem-se que para o Direito é importante que haja uma concordância entre a ação e a lei, não importando os anseios que motivaram o sujeito a agir (Cf. DURÃO, 1998, p. 115), pois a lei moral e a lei jurídica encontram-se separados por uma vala abissal, haja vista que a "[...] a legislação jurídica aceita que uma ação possa ser cumprida em conformidade ao dever, sem se interessar pelas inclinações ou interesses que a determinam, cuidando simplesmente de sua legalidade" (PEREIRA, 2012, p. 126); característica esta - legalidade; essencial, pois nela e a partir dela encontra-se a fonte de onde jorram resquícios os quais embasam o Direito e sua (consequente) lei jurídica, e ainda seus reflexos no âmbito da moral, os quais, como demonstrados, maculam o espírito do agir moral, pois neste não é possível enquadrar intuito algum que não o próprio agir por dever; enquanto na esfera jurídico-legal não há essa necessidade.

Assim sendo, e à guisa de compreensão, faz-se mister elencar o exemplo apresentado por Kant quando, ao versar sobre a catequese (ensino) moral, utiliza-se de um diálogo entre o Mestre e ao Aluno:

[...] Mestre:[...] Supõe, por exemplo, que surge uma situação na qual poderias obter um grande benefício para ti mesmo ou teu amigo, elaborando uma mentira sutil que não prejudicaria ninguém: o que diz tua razão a respeito disso?

Aluno: Que não devo mentir, não importa quão grandes pudessem ser os benefícios para mim e meu amigo. Mentir é torpe e torna o ser humano indigno da felicidade. Aqui existe uma necessidade incondicional através de um comando (ou proibição) da razão que tenho que obedecer; e perante ele todas as minhas inclinações devem silenciar.

Mestre: Como chamamos essa necessidade, que a razão impõe diretamente a um ser humano, de agir conforme a lei da razão?

Aluno: Chamamo-la de dever.

Mestre: Portanto, a observância deste dever por parte de um ser humano constitui a condição universal e única de ser digno da felicidade, e este seu ser digno da felicidade é idêntico à sua observância da virtude. [...]. (KANT, 2003, p. 322)

Vislumbra-se, a partir daí, que não há alternativa para Kant, senão agir de acordo com os ditames da razão, ou, consoante à moral.

Tal exemplo utilizado pelo filósofo é por demais esclarecedor, tanto que Durão se apodera de um elemento - a mentira; e traz à reflexão mais um exemplo, 
envolvendo-o na trama moral apregoada por Kant:

no caso concreto [...] do assassino que bate a nossa porta buscando um amigo nosso que encontra-se refugiado, a nossa resposta verdadeira ou mentirosa para o assassino pode custar a vida de uma pessoa. Trata-se, portanto, de um dilema no qual ou transgredimos o princípio ético-jurídico de ser sinceros em todas as nossas declarações com uma mentira, o que poderia salvar a vida de nosso amigo, ou nos mantemos fiéis ao primeiro princípio e dizemos a verdade colaborando, mesmo que contra a nossa vontade, à perpetração de um assassinato, o que transgride outro princípio ético-jurídico. (DURÃO, 1998, p. 105)

Eis que o sujeito, na referida situação, encontra-se diante de um dilema jurídico-moral, e tal como deixa evidente Kant em seu escrito, não é possível ao indivíduo querer harmonizar seu querer, concomitantemente, tanto ao princípio moral, quanto à lei jurídica; exigindo dele um único posicionamento, pois, como segue o supradito autor "Kant afirma que não podem existir princípios morais híbridos e que aceitar um suposto direito de mentir, mesmo que seja por filantropia, é que pode colocar em risco a humanidade" (DURÃO, 1998, p. 107); pois para o filósofo admitir um meio-termo no que toca aos preceitos morais desvirtuá-los-iam, haja vista "as leis morais [...serem] sempre categóricas e [... terem] obrigatoriedade, i.e. necessitação moral a uma ação. A ação a que sou necessitado pelas leis morais é o dever" (MATTOS, 2010, p. 108). Esse posicionamento confirma o mote do imperativo categórico querido por Kant, pois denota que não se coadunam os elementos inerentes à moralidade àqueles que pertencem à legalidade, pois enquanto aquela preza pelo estrito cumprimento do dever pelo dever, esta última compreende uma ação mais preocupada com a lei em si, olvidando-se do essencial: a concretização da moral.

\section{Sobre a violação do dever jurídico com vistas à observância de um preceito moral em Kant}

As perspectivas alusivas ao imperativo categórico, bem como a relação deste e, consequentemente, da moral - com a legalidade, apontam, ainda, para um terceiro cenário: pode um dever jurídico entrar em conflito com um dever moral? $\mathrm{E}$ ainda: a qual desses deveres deve o indivíduo se submeter? A resposta à primeira pergunta é positiva. Apesar de ambas se fundarem na razão, a lei jurídica, diferentemente da lei moral, é estabelecida no caso concreto, pelas leis de um Estado. Assim sendo, "a universalidade da lei moral contrasta com o caráter particular da lei civil” (BAPTISTA 2004, p. 108), e eventualmente, os legisladores podem se desviar da reta razão e instituir leis que violem o direito natural, surgindo a possibilidade de ambas traçarem caminhos distintos. O próprio Kant admite essa possibilidade: 
se alguma vez na constituição de um Estado ou nas relações entre Estados se encontrarem defeitos que não foi possível impedir, é um dever, sobretudo para os chefes de Estado, refletir o modo como eles se poderiam, logo que possível, corrigir e coadunar-se com o direito natural, tal como ele se oferece aos nossos olhos como modelo na ideia da razão, mesmo que tenha de custar o sacrifício do amor-próprio. (KANT, 2009, p. 166).

Conforme já indicado, não é possível admitir exceções ao dever dos sujeitos de guiarem pelos preceitos morais. Contudo, de outro lado, violar uma lei jurídica redundará em punição por parte do Estado. O caminho então seria opor resistência ao Estado e, por meio revolucionário, instituir uma nova Constituição que observe os deveres morais? A reposta de Kant não parecer ser positiva, conforme argumentos que se passa a expor.

Primeiramente, faz-se mister trazer à baila essa dinâmica entre o aspecto moral e a legislação jurídica. Sob a ótica do esboço moral de Kant, cujos elementos esbarram em situações do cotidiano, tais como quanto ao descumprimento de uma lei considerada injusta ou como no dilema do assassino que bate à porta à procura de alguém; tem-se claro, de certa maneira, que nesse colidir de preceitos, à primeira vista, a lei jurídica parece prevalecer, entretanto, conforme se depreende das lições ora analisadas, o aspecto moral tem seus requintes e forja um emaranhado de elementos os quais fornecem um substrato capaz de alicerçar uma moralidade consistente porque fundamentada na universalidade e é justamente neste aspecto que há a elevação da moralidade frente à legislação jurídica.

Esse viés da universalização, tão marcante e distinto no Imperativo Categórico, é também perseguido pelos críticos de Kant quanto ao posicionamento rigorista do filósofo; contudo é salutar revelar o exposto por Faggion quando, ao defender a proposta de moral kantiana, didaticamente expressa:

[...] uma máxima geralmente expressa as circunstâncias de sua aplicação. Só as mais gerais são aplicáveis em qualquer contexto. Assim, aparentemente, quando uma máxima é testada tem-se: 1) a candidata à máxima - eu quero $x$, então que quero fazer y em circunstâncias z; 2) a submissão ao teste de universalização - todos os seres racionais (não só os que querem $x$ ) podem querer fazer y em circunstâncias z. Esta observação parece útil, uma vez que há uma propensão para que se pense em uma ética universal como uma ética que não permite ao sujeito considerações referentes ao contexto em que a ação é executada. (FAGGION, 2003, p. 53)

Assim sendo, visualizam-se possibilidades para a prática moral, sendo possível pensar uma ética universal pautando-se no contexto no qual a ação é executada.

Isto posto, há que se considerar os meandros da legislação jurídica, pois nela 
há outras peculiaridades a partir das quais compreender-se-ão os modos como moral e legalidade se esbarram na proposta jusfilosófica de Kant. Tanto essa relação é evidente que Almeida (2006, p. 217) enfatiza que as leis jurídicas podem ser "conceituadas" (caracterizadas) como leis morais, ou constituírem-se uma subclasse das leis morais, pois:

[...] as leis jurídicas podem ser caracterizadas como leis que exigem o que pode ser exigido moralmente de todos, portanto incondicionalmente (e é nesse sentido que as leis jurídicas são, sem mais leis morais), mas que o exigem também daqueles que, embora saibam o que a lei moral exige deles, não querem se conformar a ela, e só o fazem sob a condição de seu interesse privado ou se forem coagidos a isso (e é nesse sentido que elas constituem, uma subclasse das leis morais). (ALMEIDA, 2006, p. 217)

Verifica-se, de imediato, que embora cada uma preceitue de modo discrepante, a relação entre ambas é fator preponderante, pois o Direito se caracteriza pela faculdade ou autorização moral de fazer o que é lícito ou obrigatório e de não fazer o que é proibido e, ainda, possibilita ao indivíduo coagir pela força quem o impede de agir. Sendo assim, tem-se que o Direito para Kant não assume um lugar qualquer, mas está imbuído de características essenciais:

o direito, na perspectiva de Kant, constitui-se a partir de dois princípios básicos: um, permite avaliar e decidir a priori se uma ação é ou não conforme ao direito; outro, determina que seja necessária a execução de uma dada ação para garantir a conformidade ao direito. (MACHADO, 2011, p. 3)

E essa conformidade ao Direito é alcançada (em muitas circunstâncias) por meio da coação/coerção - haja vista ser esta uma característica intrínseca à legislação jurídica; sendo isto o que diferencia da virtude (moral):

o que essencialmente distingue um dever de virtude de um dever de direito é que o constrangimento externo a este último tipo de dever é moralmente possível, enquanto o primeiro é baseado somente no livre auto-constrangimento [sic]. (KANT, 2003, p. 227)

Evidenciado está uma relação próxima, mas ao mesmo tempo distante, pois embora se trate de um mesmo conceito (dever), cada qual, inserido em seu contexto carrega uma gama de singularidades, dentre as quais se destaca a presente no enunciado de Pereira:

o direito se ocupa da legislação prática externa de uma pessoa em relação à outra. Ele realiza a liberdade do agir externo na convivência com os demais, visto que no direito o que é fundamental é que a ação se exterioriza. O direito é a forma universal da coexistência das liberdades individuais. (PEREIRA, 2012, p. 124) 
Nessa exteriorização verifica-se um dever mais propenso (senão todo imerso) a uma adequação ao contexto empírico, e não com a execução do dever pelo dever. Sobre tal situação, e à guisa de complementação, convém destacar o pensamento de Peres quando elenca que:

o direito não pressupõe a moralidade das ações, ou seja, na medida em que ele se põe como o conjunto das condições a partir das quais os diversos arbítrios podem ser unificados segundo uma lei universal, não precisa esperar, para uma tal união, que os diversos agentes ajam apenas tendo como princípio determinante de suas ações uma intenção moralmente boa, que ajam todos por dever e que sejam todos virtuosos. (PERES, 1998, p. 55)

Resta esclarecido que não há como inferir moralidade de uma ação consoante preceitos jurídicos, muito embora tal ação possa se coadunar a elementos referentes à moralidade; mas o que deve prevalecer é o que é intrínseco ao direito de fato: "o dever imposto por direito não corresponde, porém, a um dever moral, mas sim a uma genuína obrigação jurídica” (HECK, 1998b, p. 384); característica essa essencial, posto que, enquanto ação moral, somente a razão prática pode determiná-la; já a ação que atende aos princípios da legislação jurídica pode encontrar outra motivação, tais como motivos empíricos ou inclinações quaisquer.

É de suma importância enfatizar que a moralidade se ocupa em estabelecer uma lei universal (DIFANTE, 2011, p. 6o) e esta somente é possível pois emana de postulados da razão prática, enquanto que:

o princípio geral do direito, origem de toda e qualquer máxima jurídica, não possui em Kant o estatuto do imperativo categórico. $\mathrm{O}$ princípio jurídico maior não exige que seja motivo da ação justa, diferentemente da ética kantiana, onde a ação moral só pode ser engendrada pelo dever de possuir a lei moral por princípio. Em Kant, o direito não realiza a ética senão que a complementa. (HECK, 1998a, p. 56)

É nessa complementaridade que é possível encontrar uma solução aos questionamentos inicialmente postulados, pois em todos os elementos enfatizados, percebe-se que o Imperativo Categórico - germe da moral; assume uma função exclusiva, peculiar, conduzindo o indivíduo à construção do mosaico moral; colocando-se, por vezes, à frente de deveres, os quais exigem dele um único posicionamento frente às possibilidades: agir conforme os preceitos da moral, ou consoante o preconizado pela lei jurídica.

E nessa dicotomia, o que deve ser evidenciado é que o conflito apenas exige uma postura, por vezes aparentemente discrepante, mas quando se foca, tanto na questão moral, quanto no aspecto da lei jurídica, há uma única resposta, vez que o conflito se dá, somente, em âmbito subjetivo, haja vista ser impossível haver 
conflitos entre deveres objetivamente. Desse modo, Durão apregoa que:

na lei moral, ou objetivamente, os mandamentos 'não deves mentir' e 'não deves matar ou colaborar com assassinatos' não se contradizem. Ambos proíbem categoricamente essas transgressões como contrárias ao dever. Porém, na consciência do dono da casa a situação concreta gera um conflito de deveres, pois ele tem que decidir qual princípio moral, que o obriga, será respeitado e qual violado. A solução kantiana prevê explicitamente que no caso de um conflito subjetivo de deveres, no qual duas razões se opõem entre si, não podemos encontrar uma posição intermediária entre os deveres, nenhuma regra de prudência pode ser aceita como válida; também não podemos modificar os princípios pondo abaixo sua forma categórica, tornando-os condicionados, como no caso de admitir a possibilidade de um direito de mentir [...]. (DURÃO, 1998, p. 120)

Resta claro, portanto, que independentemente da situação, para Kant, não há qualquer abertura à possibilidade de não agir moralmente, mesmo que a ação moral empreendida acarrete um problema posterior.

Tal posicionamento escancara o que fora, de fato, propugnado por Kant; evidenciando-se uma crítica aos seus opositores, os quais afirmaram que ele apenas apresentou uma moral inaplicável na prática, insensível ao contexto. Diante dessa circunstância, tem-se que não é possível confundir a categoricidade do Imperativo Categórico com rigorismo:

[...] pois isso só ocorreria no caso de que a aplicação fosse imediata, Kant porém considera que eles tem que ser mediados por uma capacidade de julgar a aplicação no caso concreto. Contudo, essa capacidade de julgar não pode transformar os princípios, introduzindo-lhes exceções e condições que afetam sua universalidade [...]. A aplicação de princípios não pode subverte-los, pois tem que manter a mais estrita observância dos princípios morais." (DURÃO, 1998, p. 122)

E é justamente nessa não-possiblidade de alteração dos princípios morais de acordo com o caso concreto, impedindo assim, adaptação, que o filósofo encontrou um respaldo, ou melhor, ancorou seu imperativo categórico e, consequentemente, a moral - preceito universal e invariável.

Dessarte, tem-se que tal preceito categórico quisto por Kant assume fundamental importância, posto que arraigado na universalidade e, desse modo, preservado das limitações materiais. Ainda, apresenta outra particularidade, mormente em paralelo à legislação jurídica quanto ao alcance desta frente ao direito de resistência por parte do indivíduo.

O filósofo alemão não admite que o cidadão tem direito de resistir ao Estado, ou seja, deixar de cumprir a lei, mesmo quando injusta, não é um direito, 
inviabilizando qualquer possível investida no sentido de gerar uma revolução, pois ela "[...] pode fazer nascer um estado ainda mais totalitário, violando frontalmente um dever moral de buscar um estado mais justo" (FREITAS, 2014, p. 87).

E essa inexequibilidade quanto ao direito de resistir é fomentada por Kant em sua construção doutrinária, pois para ele o Estado Civil está fundamentado no Contrato Social, mas este é, apenas, um fato ideal e não algo construído historicamente e, por isso, não podem os cidadãos questionarem sua legitimidade. Segue ainda, para corroborar tal ideia, afirmando que o Soberano, detentor do poder supremo, ordena, e todos devem se submeter às suas decisões, mas ele próprio a ninguém deve "prostração":

cada membro da comunidade possui um direito de coação sobre todos os outros, excetuando apenas o chefe do Estado (porque ele não é membro desse corpo, mas o seu criador ou conservador), o qual é o único que tem poder de constranger, sem ele próprio estar sujeito a uma lei coercitiva. Porém, todo o que num Estado se encontra sob leis é súdito, por conseguinte, sujeito ao direito de constrangimento, como todos os outros membros do corpo comum; a única exceção (pessoa física ou moral) é o chefe do Estado, pelo qual se pode exercer coação de direito. Com efeito, se ele também pudesse ser constrangido, não seria o chefe do Estado e a série/ascendente da subordinação iria até o infinito. (KANT, 2009, p.8o)

Ainda neste raciocínio, se houvesse a possibilidade de o povo resistir (leia-se, deixar de cumprir/rebelar-se), criar-se-ia um sistema autofágico, pois ao mesmo tempo que se eleva o soberano, confere um poder ao povo de destruí-lo, ferindo um princípio fundamental da soberania. E, a partir disso, conforme apregoa Freitas, "para o filósofo de Königsberg é preferível a tirania à anarquia, é melhor um governo tirano do que não ter um Estado Civil e se retornar ao estado de natureza" (FREITAS, 2014, p. 80). Vê-se, portanto, a afeição tamanha por parte do jusfilósofo à constituição civil, ainda que seja pífia, pois é combatendo a resistência que se salvaguarda o direito e, se universalizado o direito de resistência, haverá o aniquilamento da constituição civil.

Diante de tais circunstâncias, tem-se que Kant não adere às "revoluções" abruptas e violentas, pois ao invés de aprimorar o Estado, há grandes probabilidades de se gerar os mesmos erros e não atingir os propósitos almejados.

Assim sendo, diante desse paradoxo, que de um lado impõe a necessidade de se observar o dever moral e, ao mesmo tempo, a vedação a um direito a resistência, a reposta está na possibilidade de desobediência civil. Parece ser essa a saída que o jusfilósofo deixa transparecer como solução para o antagonismo oriundo de uma Constituição injusta, enfatizando acerca da possibilidade de transgredir uma lei com vistas à observância de um preceito moral: 
quando a lei moral e a positiva estão em conflito, não há necessidade kantiana a obedecer à lei positiva. Nesse caso, existe a possibilidade kantiana de desobediência civil no ato de seguir a lei moral, sob a condição de se estar preparado para aceitar as repercussões legais de suas ações (WIT, 2009, p. 298 apud FREITAS, 2014, p. 94).

Tem-se nesse pensamento que Kant permite a não observância da lei positiva quando conflitar com a lei moral, contudo, como se depreende da assertiva deve o agente aceitar o resultado oriundo de tal ato, ou seja, embora a lei jurídica deva ser arquitetada com vistas à sua plena justiça, pode ser que ela não atinja tal fim, ensejando uma legislação injusta e, dessa forma, em confronto com preceitos morais. E quando isso ocorrer, consoante Kant, ao indivíduo é facultado deixar de cumprir a norma legal para coadunar-se ao preceito moral, ciente de que essa atitude poderá lhe trazer infortúnios perante o Estado.

\section{Conclusão}

As nuances elencadas permitiram um olhar mais apurado a respeito da proposta moral apregoada por Immanuel Kant e, consequentemente, a efetivação desta quando de seu encontro com a legislação jurídica.

Primeiramente, pode-se perceber o alcance do Imperativo Categórico, suas perspectivas e, sobretudo, vislumbrar nele a única possibilidade de se alcançar a moralidade plena, pois é a partir dele que se extrai o viés da universalidade, elemento central à consecução do agir moral.

Posteriormente, analisou-se a relação desse Imperativo Categórico frente à legalidade, evidenciando-se que não há qualquer similitude entre ambos, pois enquanto àquele remete, unicamente, ao cumprimento do dever, simplesmente por ser dever; na legislação jurídica outros móbeis conduzem à prática de determinada ação, podendo inclusive ser por medo ou coação.

Por fim, pautou-se sobre a possibilidade de violar a lei jurídica no intuito de garantir a observância de um preceito moral; o que, em primeira instância, não pareceu factível porque o preceito legal tem suas bases assentadas em um poder estatal e, sendo assim, deve poder coagir a todos (exceto o soberano) de tal forma que ela seja, de fato, cumprida em todos os termos. E sendo assim, assumiria um papel central na organização do Estado.

De outro lado, ao verificar o aspecto da moralidade e suas peculiaridades, vislumbrou-se que é possibilitado ao sujeito transgredir uma lei jurídica visando garantir um preceito moral, estando ciente das possíveis consequências oriundas dessa desobediência civil, que é como Kant denominou essa atitude.

Em suma, verifica-se que Kant buscou, não apenas, apresentar uma proposta de ação que se queira universal, mas, e sobretudo, que esse agir pautado no 
Imperativo Categórico possa conduzir a humanidade a uma contínua melhora, conduzindo-a ao Reino dos Fins, onde todos sigam essa proposta de ação universal. Com esta finalidade, é possível ao sujeito, inclusive, desobedecer a um dever jurídico, embora, contudo, isso não signifique um direito resistência.

\section{Referências primárias}

KANT, Immanuel. A metafísica dos costumes. Tradução, textos adicionais e notas Edson Bini. Bauru, SP: EDIPRO, 2003. (Série Clássicos Edipro)

. Fundamentação da metafísica dos costumes. Tradução Paulo Quintela. Lisboa:

Edições 70, 2005.

. Immanuel. Crítica da razão prática. 2. ed.São Paulo: Martins Fontes, 2008.

Sobre a expressão corrente: isso pode ser correto na teoria, mas nada vale na

prática In: . A paz perpétua e outros opúsculos. Trad. de Artur Morão. Lisboa: Edições 70, 2009.

\section{Referências secundárias}

ANDRADE, Renata Cristina Lopes; CARVALHO, Alonso Bezerra de. O dever moral e o valor das ações humanas segundo Kant. Kínesis. Vol. IV, no 07. p. 235-244. 2012. Disponível em: <http://www.marilia.unesp.br/Home/RevistasEletronicas/Kinesis/renataandradealonsobeze rra235-244.pdf.> Acesso em 01. Jul. 2014.

ALMEIDA, Guido Antônio de. Sobre o Princípio e a Lei Universal do Direito em Kant. KRITERION, Belo Horizonte, no 114, dez/2006, p. 209-222.

ANDRADE, Renata Cristina Lopes. A moral kantiana do Dever (Sollen). Problemata: $R$. Intern. Fil. v. 5. n. 2, jun. 2014. p. 5-19.

BAPTISTA, Ligia Pavan. O pensamento político de Kant à luz de Hobbes e Rousseau. Revista Prisma Jurídico, São Paulo, v. 003, set. 2004. p. 105-117.

BECKENKAMP, Joãosinho. Sobre a moralidade do direito em Kant. ethic@. v. 8. n. 1, jun. 2009. p. 63-83.

APOLINÁRIO, José Antônio Feitosa. Nietzsche e Kant: sobre a crítica e a fundamentação da moral. Recife: Ed. Universitária da UFPE, 2012.

CANDIOTTO, Cesar. Ética: abordagens e perspectivas.2. ed. rev. e ampl.Curitiba: Champagnat, 2011. (Coleção Didática; 1).

DIFANTE, Édison Martinho. A regra moral e os princípios práticos do agir em Kant. PERI. v. 03. n. 02, 2011. p. 58-78.

DURÃO, Aylton Barbieri. Kant e o Suposto Direito de Mentir por Filantropia. Philosophica. n.12, Lisboa, 1998, p. 97-127.

DURÃO, Aylton Barbieri. A fundamentação do Estado de Direito. Philosophica. n. 23, Lisboa, 2004, p. 5-19.

FAGGION, Andréa Luisa Bucchile. O imperativo categórico como realização da necessidade lógica da razão. Revista de Filosofia, Curitiba, v. 15. n. 17, jul./dez. 2003. p. 43-53. 
Sobre a possibilidade de violar um dever jurídico com vistas à observância de um preceito moral segundo Kant

FREITAS, Valter. A interpretação liberal do estado em Kant e o problema da resistência. 2014. 106 f. Dissertação (Mestrado em Filosofia) - Universidade Estadual do Oeste do Paraná.Câmpus Toledo. Centro de Ciências Humanas e Sociais. 2014.

HECK, José N. Direito e Lei em I. Kant. Síntese, Belo Horizonte, v.25, n.8o, p.43-73, 1998a.

HECK, José N. Moral e direito racional: um estudo comparativo entre Kant, Rousseau e Hobbes. Síntese. Belo Horizonte, v. 25, n. 82, 1998b, p. 369 - 390.

HECK, José N. Kant e os princípios de Ulpiano: a erradicação da doutrina do direito natural. ethic@, v. 8, n. 2,p. 229-245, 2009.

HÖFFE, Otfried. O imperativo categórico do direito: uma interpretação da "Introdução à Doutrina do Direito". Studia Kantiana. v. 1, n. 1, p. 203- 236, 1998.

LIMA, Erick Calheiros. Observações sobre a Fundamentação Moral do Direito em Kant. ethic@. Florianópolis, v. 4, n. 2, p. 141-155, Dez 2005.

LOPARIC, Zeljko. As duas metafísicas de Kant. Kant e-Prints. Vol. 2, n. 5, 2003, p. 1-10.

MACHADO, Luís Deodato R.. Algumas observações sobre o princípio e a lei universal do direito em Kant. Seara Filosófica. N. 4, Verão, 2011. P. 3-13.

MATTOS, Fernando Costa. Introdução ao Direito Natural Feyerabend, de Immanuel Kant. Cadernos de filosofia alemã. São Paulo, no 15, p. 97 - 113, jan./jun. 2010.

OLIVEIRA, Manfredo Araújo de. A herança de Kant: A vinculação radical entre razão, liberdade e ética. CadernosIHU em formação. Rio Grande do Sul: Unisinos. Ano 1.n 2.2005.p. 10-12.

PAVÃO, Aguinaldo. Heteronomia e imputabilidade na fundamentação da metafísica dos costumes. Kriterion. Belo Horizonte, vol.43 n.105, p. 119 - 135, jan./jun. 2002.

PAVÃO, Aguinaldo. O caráter insondável das ações Morais em Kant. Revista Transformação. Universidade Estadual Paulista/ Unesp.v.30.2007.p.101-114.

PEREIRA, Regina Coeli Barbosa. PEREIRA, Rosilene de Oliveira. Kant e os Fundamentos do Direito Moderno. Cadernos da EMARF, Fenomenologia e Direito. Rio de Janeiro, v.5, n.1, p.123-138, abr./set.2012.

PERES, Daniel Tourinho. Imperativo Categórico e doutrina do direito. Cadernos de Filosofia Alemã 4, 1998, p. 43-64.

PEREZ, Daniel Omar. Kant: A Lei Moral. In: SGANZERLA, Anor; FALABRETTI, Ericson Sávio; BOCCA, Francisco Verardi (orgs.). Ética em movimento. São Paulo: Paulus, 2009, (Coleção Filosofia).

PINHEIRO, Celso de Moraes. Liberdade e Coação no Direito de Kant. VERITAS. Porto Alegre, v. 52, n. 1, março/2007. p. 15-24.

PINZANI, Alessandro. O papel sistemático das regras pseudo-ulpianas na Doutrina do Direito de Kant. Studia Kantiana, n. 8, 2009. p. 94-120.

ROHDEN, Valério. Uma ética motivada pelo desejo de realização da humanidade. CadernosIHU em formação. Rio Grande do Sul: Unisinos. Ano 1.n 2.2005.p. 21-22.

SALGADO, Ricardo Henrique Carvalho. Kant e Kelsen. Revista brasileira de estudos políticos [RBEP]. Belo horizonte, no 96, jul.- dez., 2007, p. 343-357.

SÁNCHEZ VÁZQUEZ, Adolfo. Ética. 35. ed. Rio de Janeiro: Civilização Brasileira, 2013.

SOUZA, Hélio José dos Santos. O problema da motivação moral em Kant. São Paulo: Cultura Acadêmica, 2009. 
POERSCH, C.

TUGENDHAT, Ernst. Lições sobre ética. 5. ed. rev. e corrigida por Ernst Tugendhat e reorganizada por Ernildo Stein. Petrópolis, RJ: Vozes, 2003.

Submissão: 24.02. 2020 / Aceite: 12. 08. 2020 